\title{
The application of spatial analysis to cadastral zoning of urban areas: an example in the city of madrid.
}

\section{M.C. Morillo , F. García Cepeda and S. Martínez-Cuevas}

Spatial Analysis has been used since the 1990s for hedonic cadastral models of urban areas in large cities. This research aims to apply spatial analysis to zoning a district in Madrid located in the central part of the city in order to estimate urban housing prices. In doing so, the necessary data have been gathered, both vector and raster, as found on the official government website and private company websites. This was done firstly to analyse the characteristics and then for the objectives of the study because it is helpful to use these types of analyses based on vector and raster data along with interpolation methods that obtain regular structures and attempt to avoid the subjective component inherent to traditional procedures.

The essence of the work consisted of studying the minimum parameters that influence housing appraisals to resolve the problem. Normally, cadastral appraisal work fulfils the Official Technical Regulations in each country considering a greater number of parameters and corrective coefficients. The importance of this work consisted of lowering and prioritising the number of basic parameters necessary to set urban housing prices. The conclusions section confirms a high likelihood of successfully reducing the number of parameters to achieve an appraisal value that is similar to the one obtained using official methods.

\section{Introduction}

For centuries, human beings have established relationships with the territory in attempts to either adapt to it by accepting nature or attempting to establish a series of rules to modify the original nature (Shlomo et al., 2010; Ingram, 2014). When the Roman Empire was conquering territories, one of the first things it did was the materialisation of a new settlement. This was done based on the "decumanus maximus" and the "cardo maximus" which were crossed in the "umbilicus" (Moreno Gallo, 2004). These directions normally coincided with the N-S and E-W directions. Then, parallel lines were drawn to create a grid (Ruiz Morales, 1999; Pelletier, 1982). A similar system was followed by the Spanish colonists when establishing cities in America, giving greater importance to the centre of the city and positioning administrative and religious buildings in the bordering blocks.

Zoning is a mechanism used to assign general management objectives and priorities to different areas (zones). Upon assigning objectives and priorities to this zones, planners also define the uses they will allow and prohibit (Cano et al., 2000). It was not until the era of Napoleon I in the 19th century that European governments attempted to gain a better understanding of the territory under their control for fiscal reasons, in the case of property value registers. This soon turned into a more in-depth concept of zoning, for example: municipality, polygon, plot, and sub-plot (Metzenbaum, 1955).

Zoning Plans have been developed for cities since the mid-19th century and in more detail in the past decades (see Barcelona's Plan Cerdá (http://www.anycerda.org/ web/es/arxiu-cerda), Madrid's Castro Expansion Plan or the Arturo Soria Linear City Plan in Madrid (Navascues, 1969). Zoning has been applied in other areas such as the environment, transport, statistics ( $\mathrm{Li}$ and Wang, 2014), property valuation, etc. mostly for fiscal purposes, yet also expanding the concept of zoning. In this last case and in accordance with the provisions of the Modified Text of the 2004 Property Value Act, approved by Spanish Royal Legislative Decree 1/2004, of 5 March (http://www.catastro.meh.es/documentos/normativa).

"The municipalities in the common territorial system are classified based on their property dynamics into seven groups. The indicator for this is the MBR (the land-toroof space cost factor module). It establishes coordination criteria for the assignment of modules based on the maximum values observed for residential use. These maximum values correspond to the zones of higher value in a municipality. Under no circumstance do they refer to atypical 
typologies or exceptional market situations. In such cases where scarce market entity is manifest locally, a market study is done of the supra-municipal territory. In lack of both and based on the studies and statistical analyses that correspond, the Territorial Technical Property Coordination Boards establish reference values."

Value zones are reached via the different divisions of the territory for each valued polygon which is, in turn, set within a homogeneous area that coincides with the municipal borders. The property valuation for tax purposes is done based on an administrative document known as a Property Value Report which, among other requirements, needs a prior market study which provides a value in euros per metre squared for the various types of property, residential flats, horizontal and single-family properties, offices, business premises, garages, etc.

All of these details are defined in the text of the law and in the Technical Standards for Property Valuation for the purposes of urban property assessment. Spanish Royal Decree 1020/1993, of 25 June 1993 (Official Spanish Gazette).

The Property Value Report describes the Homogeneous Economic Areas, indicating the Basic Land to Roof Space Cost Factor Module (MBR) and Basic Construction Modules (MBC) assigned to them. Moreover, it outlines the criteria for land and structure value assessment for tax purposes which are based on the location of the property, the urban market circumstances, the cost of construction, production expenses and profits made in the development business as well as the corresponding corrective values and coefficients (http://www. catastro.minhap.es/esp/ponencia_valores.asp).

A market study provides temporary data for the real estate offering and this is used along with other resources and information to delimit value zones, indicating some parameters such as: typology, age, surface area, price $€ / \mathrm{m}^{2}$, etc. For the mass valuation of real estate, an attempt must be made to locate the most uniform zones possible within the territory subject of the study. To do so in the case of Spain, the working unit used is the municipality and then the urban land therein is divided into zones with the highest to lowest surface area to get what is known as value zones. There is a single value in these zones for the basic construction module and the basic repercussion model. These modules lead to the construction value and the land value, respectively and are uniform for the value zones yet are affected by corrective factors pursuant to the provisions of Spanish Royal Decree 1020/1993 of 25 June 1993. (García Cepeda, 2012). The basic modules are values established for each municipality by the Higher Commission for Real Estate Coordination and vary each year. For more information, see: (http://www.catastro.minhap.es/esp/faqs.asp). Internationally, there are authorities which issue appraisal rules such as the Appraisal Institute with its Uniform Appraisal Standards for Federal Land Acquisitions.

\section{Objective:}

This research aims to complete zoning to estimate urban housing prices (IAAO, 2013; FAO, 2015) using different levels of spatial disaggregation in order to reduce and prioritize the variables related to the price of urban households. The study of techniques that make it possible to work by disaggregating micro-territorial data becomes, normally, the common objective of interest in many spheres of reality (countries, regions, administrations, etc.). GIS techniques, Spline interpolations and spatial disaggregation are used in this study. All of the foregoing techniques were applied to a specific area of the city of Madrid.

\section{Mathematical approach to the study}

The price of urban homes is currently being estimated using statistics (linear regression) without considering the geographic situation of the homes. However, there are new techniques based on the first law of geography which was formulated in 1970 by geographer Waldo Tobler. It states: "Everything is related to everything else, but near things are more related than distant things" (Tobler, 1970). This implies spatial properties may be used to evenly distribute the attributes or characteristics of the study area to obtain a good price estimate as per the zone.

Therefore, spatial auto-correlation indicates that the relationship between the value of an existing variable at a given point and those of the same variable in an area near said point are correlated. This spatial auto-correlation is the formal expression of the Tobler's first law of geography. It may be positive (the nearby points reflect more similar values than the points further away) or negative (the points further away reflect more similar values than the nearby points).

One of the most common measures for quantifying the spatial auto-correlation of a variable is Moran's I parameter (Moran, 1948). Since there is spatial correlation, interpolation is first done for the disaggregation of the zone to create a regular structure based on irregularly distributed data. Raster layers can be generated based on the information in other formats (this process is called rasterization) which gather the characteristics for analysis by means of these algorithms. One interpolation method permits the calculation of values at non-sampled points based on the values gathered in another series of points.

Adaptive curves or splines comprise a family of exact, deterministic and local interpolation methods. From a physical perspective, they may be likened to situating an elastic surface over the area to be interpolated and setting this area over the known points. This creates gentle surface areas, the characteristics of which may be regulated by modifying the type of curve used or the parameters thereof just as would happen if the qualities of this fictitious membrane were to be varied (Olaya, 2015).

The surface area created complies with the condition of globally minimising the general curve of the surface area, resulting in a gentle surface area that passes exactly through the entry points. From a mathematical perspective, the splines are polynomic functions by sections in such manner that instead of using a single polynomial to adjust an entire interval, a different one is used for each section. The curves defined by these polynomials are linked together in so-called knots, which fulfils particular continuity conditions (Olaya, 2015). There are two spline methods: regularised and tension. The one used for this research is Spline with tension, as is explained below.

Later, the different layers were joined by means of map algebra. Map algebra means a set of techniques and procedures which, when operating over one or several layers in raster format, obtains derivative information, generally 
in the form of new data layers. The current definition of map algebra is the work of Dana Tomlin (Tomlin, 1990), who established the principal division of functions and gave rise to the discipline by setting out the bases for what is now the common way to do raster geographic layer analyses. These are the mathematical techniques used. The findings and some expansions and observations are outlined below.

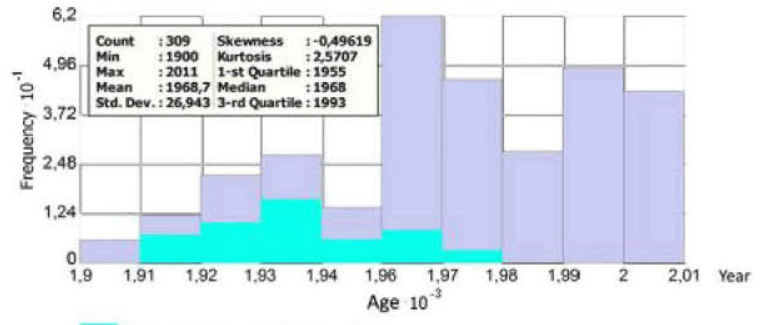

Value of the selected samples

\section{Data and methodology}

\subsection{Area of study and data}

The study was applied to a certain area of Madrid, specifically the Las Acacias neighbourhood (Figure 1). This neighbourhood has gone through major urban transformations in the last 30 years going from a nearly-abandoned semi-industrial area with a gas company, wood plants, etc. to an area quite favoured by the railway that joins the

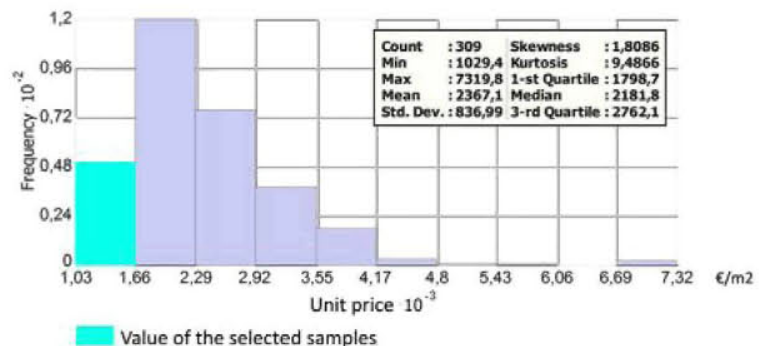

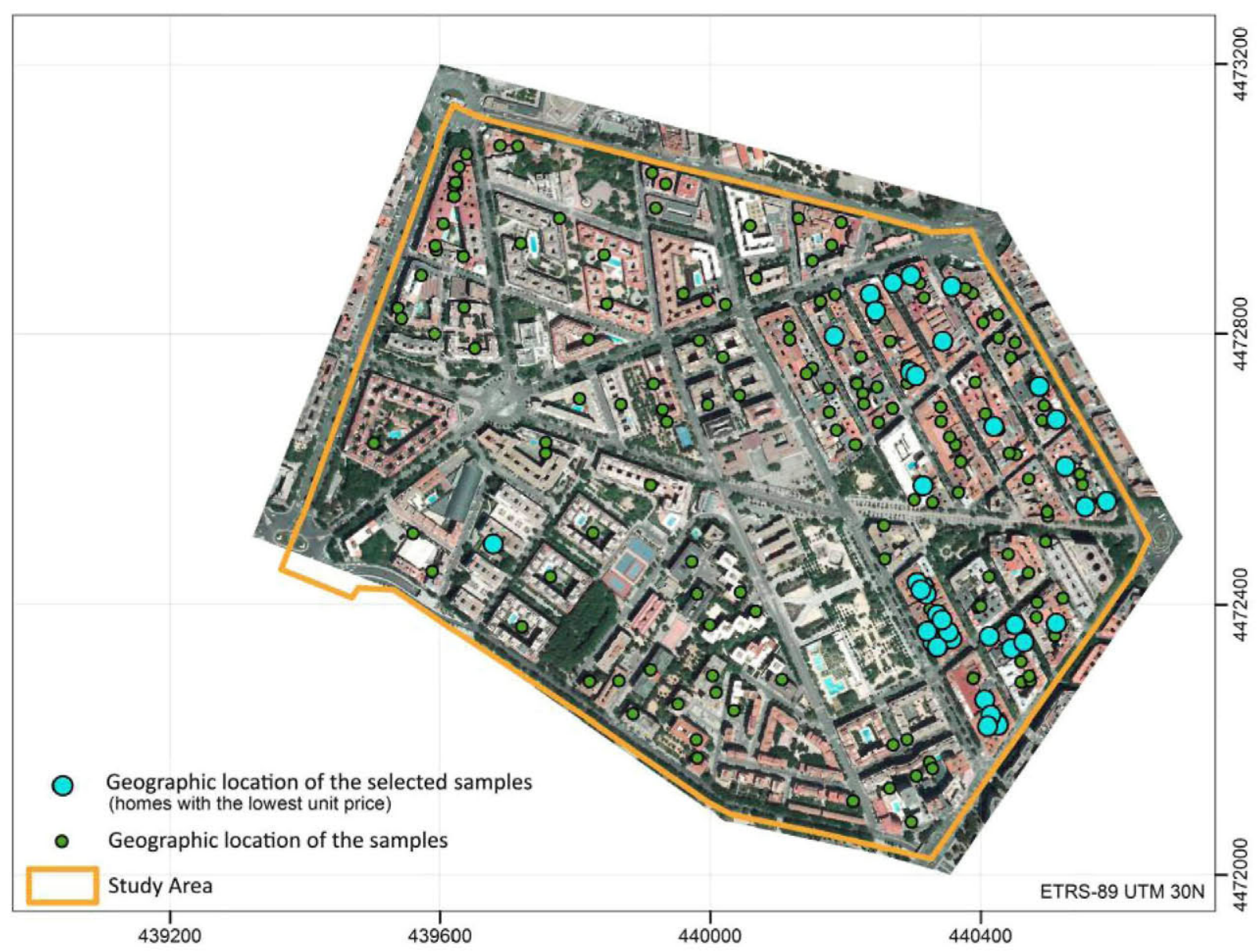
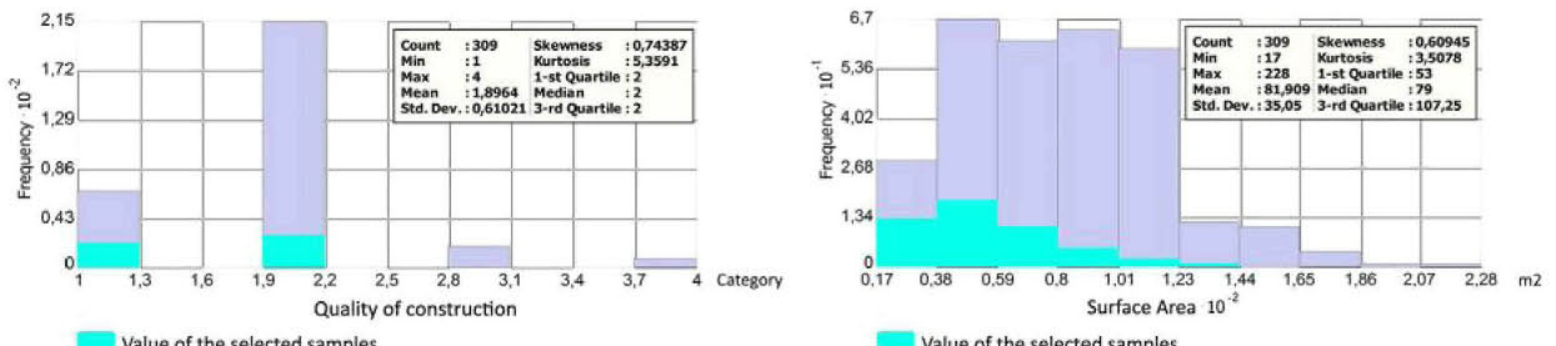

Value of the selected samples

Value of the selected samples

12014 Distribution of homes. The blue dots represent homes with the lowest unit prices. The histograms for the four variables are shown on the ends 


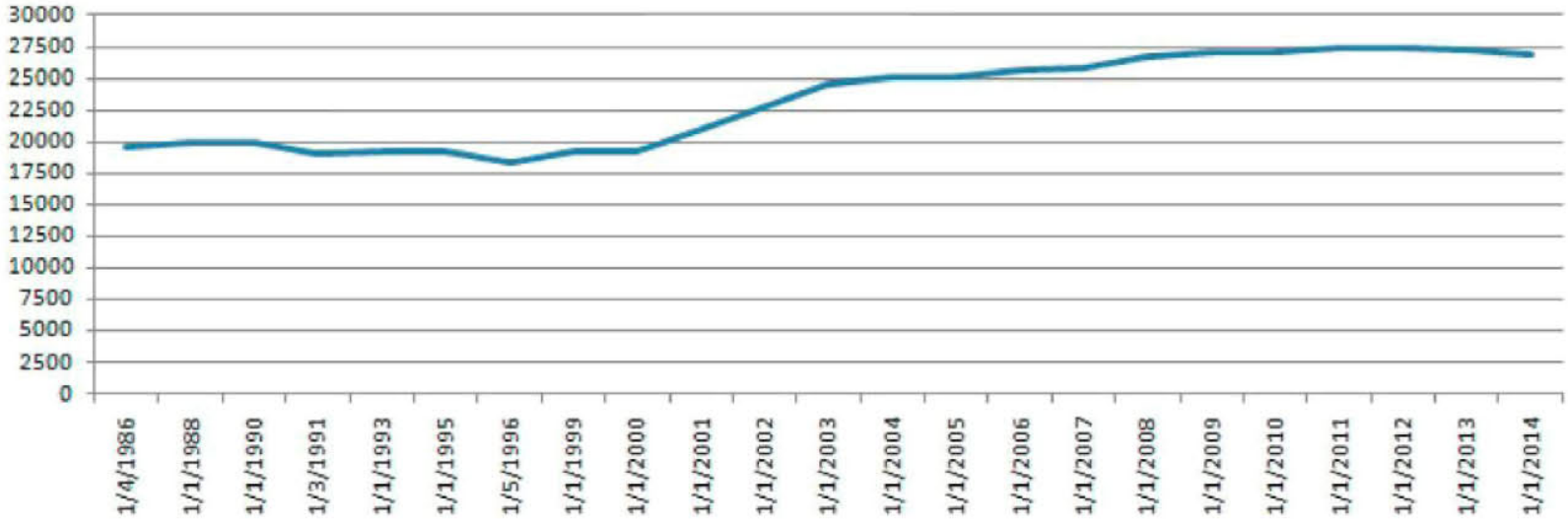

Graph 1 Evolution of the population of Acacias: 1986-2014

Atocha and Principe Pio stations being integrated underground and the construction of the Green Belt. Currently it is one of the neighbourhoods with the greatest growth both as concerns population and homes in the consolidated areas of Madrid.

The neighbourhood features a surface area of 107 ha and a population of 36,922 people with 17,250 total homes (http://www-2.munimadrid.es/TSE6/control/ seleccionDatosSeccion). Graph 1 shows the population growth during the real estate boom and the gradual loss of value throughout the years of crisis.

For this study, we used the typology indicated by the Spanish Directorate General of the Property Tax Register as 1124; in other words, housing for residential use, collective urban housing in a closed block. More than 300 samples were obtained from field data and real estate websites with a variable age of more than 100 years. The construction quality varies between 2 and 5 , where 2 represents "very high" construction quality and 5 is "low quality". The data provide the housing surface area (Figure 1).

The following information layers were arranged in shape format (ESRI) for the zoning study:

- Data on the Neighbourhood. This layer contains information relating to the characteristics of the homes, for example: surface area, price per metre squared, years of construction and quality of construction. These variables help classify the homes.

- Neighbourhood. This layer was used to delimit the study area.

- Structures. This contains the drawings of the structures from the year 1900 to the year 2011. This layer was used to see the location of the structures in the study area.

All of this information was obtained from official and commercial websites. The ortophoto is obtained from (http://www.ign.es/ign/main/index)

\subsection{Methodology}

Firstly, we conducted an Exploratory Spatial Data Analysis (ESDA) as a preliminary step before the spatial estimation of housing prices (Anselin, 1995; 2001b); (Chasco, 2003) basing ourselves on the following articles: Anselin and Le Gallo (2006); Döner (2015); Haining (1990) and others for the development of our study.
As per the publications seen: Chica et al. (1999: 2007); Jansson (2000), Caridad et al. (1997); Jahanshiri et al. (2001) and others, the fundamental micro-parameters for creating homogenous housing zones are: the surface area of the home, the quality of the building, the age of the building and the unit price $\left(\epsilon / \mathrm{m}^{2}\right)$.

The surface area refers to that of the home without considering the plot on which it is built since work is done with residential urban real estate where the building occupies all of the land. The price per metre squared is relative to that of the home. The age of the building is obtained from market studies and the cadastral headquarters website. Finally, the quality was estimated on a scale of 1 to 4 where 1 is the worst quality and 4 , the best quality.

All of them were obtained from the Spanish Directorate General for the Land Registry, Fotocasa and Idealista, accessed 2015.

The work was divided into 4 phases:

(i) Data collection. The study area has a surface area of 107.42 ha, working with a confidence level of $95 \%$ and a sample error of less than or equal to $6 \%$. Therefore a minimum of 267 random samples was required. Our study was completed with 309 samples which complies with the established confidence and error rates.

(ii) Spatial study of the variables.

(iii) Zoning of each one of the variables and zonal intersection.

(iv) Validation of the zoning obtained by Spline Interpolation (SIZ) and Property Value Zones (ZVC).

Zones were identified in the spatial study for the aforementioned four parameters. The geographic position of the different value combinations were studied for the variables, as can be seen in Figure 1. The relationships between the variables were studied (Figure 2). The trends in the different variables, for example, the trend in unit price (Figure 3 ).

The study of the variability of the different variables, for example, shows the variability of the unit prices with the Voronoi polygons using entropy. The Voronoi map was built based on identifying the Thiessen polygons for the sample points. These polygons geometrically establish the borders of the closest points to each one of them. They are shown in different colours in accordance with the sections drawn up for five different categories 

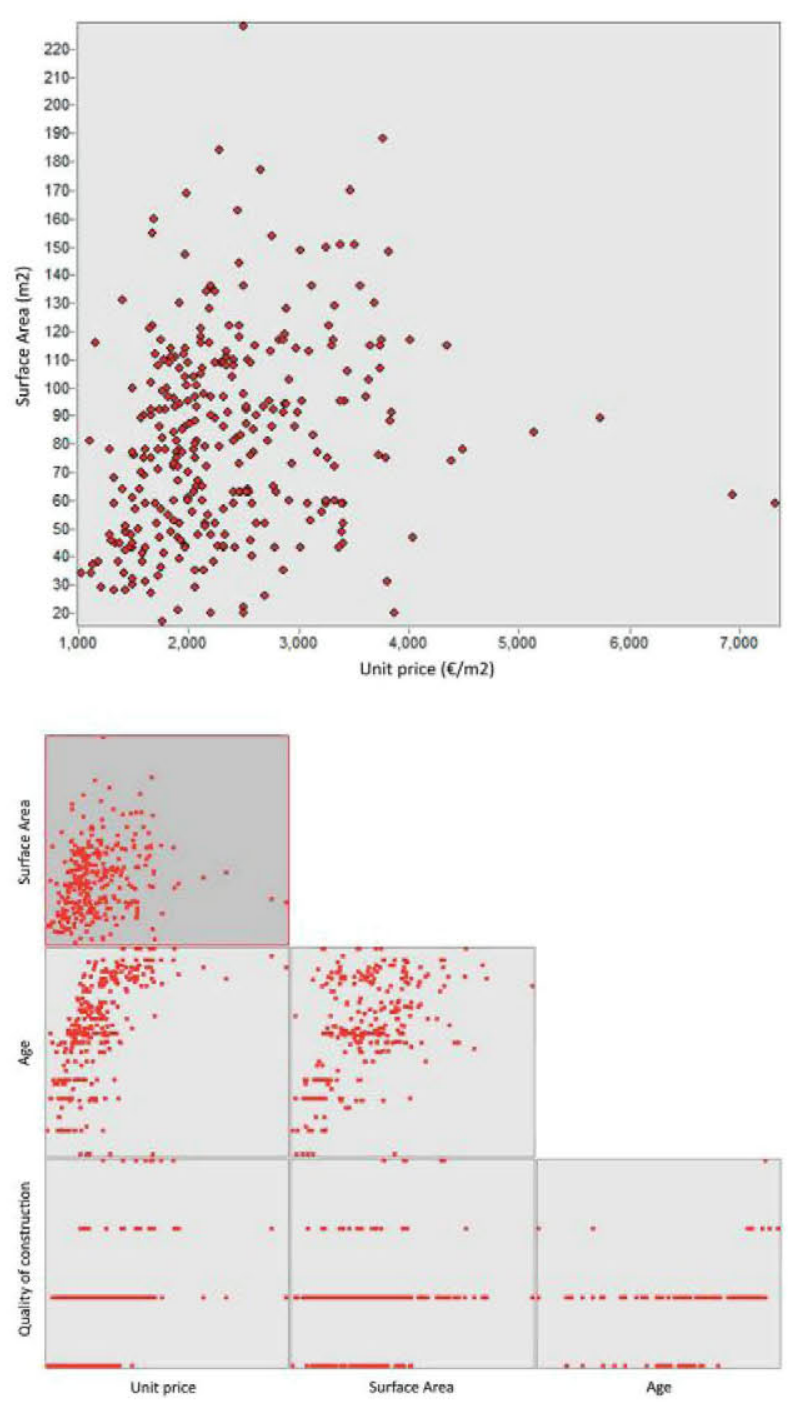

2 The upper right-hand side: Dispersion matrix, abscissae: Unit prices, ordinates: Surface area of the homes. The histograms and dispersion diagrams for the four study variables are shown in the lower left-hand corner

according to the value obtained (Santos Preciados, 2011). The polygons are drawn by applying the different calculation procedures. The one used for our research was:

Entropy (Figure 4): All of the cells are placed in five classes based on a natural grouping of data values (smart quantiles). The value assigned to a cell is the entropy calculated based on the cell and the neighbouring cells; in other words,

$$
\text { Entropy }=-\Sigma\left(p_{i} * \log p_{i}\right),
$$

where $p_{\mathrm{i}}$ is the proportion of cells assigned to each one of the five classes indicated.

The most important conclusions obtained from the descriptive spatial study were to establish the distribution of the different variables as per their geographic situation; for example, the new structures (year 2011) can be observed in the north-western part. The trend in flat prices shows a slightly higher value in the northern part in comparison to the southern part and there is price variability in the centre - southern part (Figure 3, blue). Moreover, the spatial study made it possible to do a detailed data purge from 344 to 309 homes.
Once the spatial study was completed, a structural analysis was done. Firstly, the spatial auto-correlation was observed between the unit prices of the homes via the Moran Global Index. The mathematical equation used for the Moran Global Index is as follows:

$$
I=\frac{N \sum_{i=1}^{n} \sum_{j=1}^{n} w_{i j}\left(x_{i}-\bar{x}\right)\left(x_{j}-\bar{x}\right)}{\left(\sum_{i=1}^{n} \sum_{j=1}^{n} w_{i j}\right) \sum_{i=1}^{n}\left(x_{i}-\bar{x}\right)^{2}}
$$

where $\mathrm{N}$ is the number of cases, $\mathrm{xi}$ is the value of the variable of a specific location and $x j$ is the value of the variable in another location (where $\mathrm{i} \neq \mathrm{j}$ ), $\overline{\mathrm{x}}$ is the average of the variable and wij is the weight applied for comparison between location $i$ and location $j$. This index is accompanied by a hypothesis test under an assumption of normality. Null hypothesis $(\mathrm{H}=0)$ states there is no spatial auto-correlation.

To calculate the indices, it is first necessary to obtain a list of neighbours for each one of the areas which is later used to obtain a weight matrix. The neighbour or closeness criteria on which the indices are based refer to common borders between the areas. There are other criteria related to distance ranges, or k-neighbours, among others (Sánchez, 2004)

Using the Euclidean Distance Method for inverse distance spatial relations, a value was obtained in this study for the contrast statistic $\mathrm{z}=22.2$ and the corresponding p-value of approximately zero. The conclusion reached is the prices show no random distribution; in other words, the data pattern is a cluster given the positive statistical contrast. A flat distribution study was then done using the four variables (area, unit price, age and quality of construction). Spline interpolation was used for this.

\section{Spline Equation}

The algorithm the Spline tool uses is based on the following formula for surface area interpolation (http://help. arcgis.com):

$$
\mathrm{S}(\mathrm{x}, \mathrm{y})=\mathrm{T}(\mathrm{x}, \mathrm{y})+\sum_{\mathrm{j}=1}^{\mathrm{N}} \lambda_{\mathrm{j}} \mathrm{R}\left(\mathrm{r}_{\mathrm{j}}\right)
$$

where:

$$
\mathrm{j}=1,2, \ldots, \mathrm{N}
$$

$\mathrm{N}$ is the quantity of points.

$\lambda \mathrm{j}$ are coefficients determined by the resolution of a system of linear equations.

$\mathrm{rj}$ is the distance from point $(\mathrm{x}, \mathrm{y})$ to point $\mathrm{j}$.

$\mathrm{T}(\mathrm{x}, \mathrm{y})$ and $\mathrm{R}(\mathrm{r})$ are defined for the option used.

We suggest using the Tension option where sudden changes in values can reflect significant artificial oscillations. We suggest a solution using splines with tension (Mitásová, 1993). The inclusion of tension is a direction can add an anisotropic dimension to the interpolation process (Schweikert, 1966). Therefore:

$$
\mathrm{T}(\mathrm{x}, \mathrm{y})=\mathrm{a}_{1}
$$

$\mathrm{T}(\mathrm{x}, \mathrm{y})=\mathrm{a}_{1}$

where: $a_{1}$ is a coefficient determined by solving a system of linear equations. 


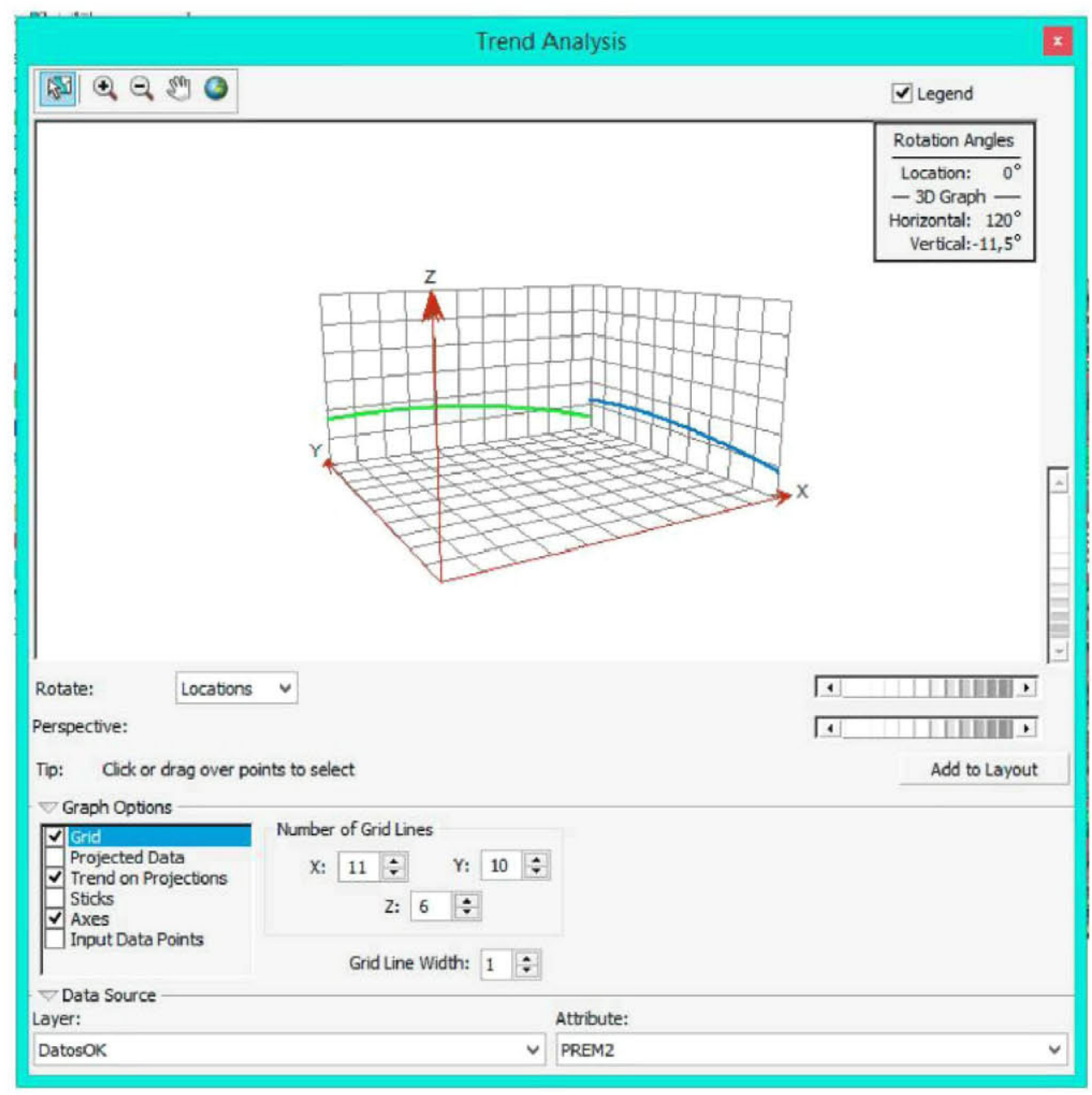

3 Graph of trends in unit prices. In our case, there's an E-W trend (green curve) and an N-S trend (blue curve)

$$
\mathrm{R}(\mathrm{r})=-\frac{1}{2 \pi \phi^{2}}\left[\ln \left(\frac{\mathrm{r} \varphi}{2}\right)+\mathrm{c}+\mathrm{K}_{0}(\mathrm{r} \varphi)\right]
$$

where:

$\mathrm{r}$ is the distance between the point and the sample.

$\varphi^{2}$ is the weighted parameter.

Ko is the modified Bessel function.

$\mathrm{c}$ is a constant equal to 0.577215 .

In order to complete the zoning for a location, we used Spline interpolation with tension for each one of the attributes (unit price, surface area, years of construction and category); the rasters obtained were cropped with a block layer.

Once the interpolation was finished, a new classification was done for each one of the variables in order to have the same units of measure for the four variables. In other words, each one of the variables was weighted in percentages and then the four raster layers were intersected (Figure 5). Once this intersection was completed, the zoning was done in four zones (Figure 6) where each zone represents:

- Zone 1, flats with the lowest prices of around $€ 1700$ / $\mathrm{m}^{2}$, a small surface area of around $50 \mathrm{~m}^{2}$, an average construction date of the year 1937, with a value of 1.56 in quality. This zone includes $50 \%$ of the cheapest flats in the study.

- Zone 2, flats with prices above category 1 of around $€ 2000 / \mathrm{m}^{2}$, a surface area of around $70 \mathrm{~m}^{2}$, an average construction date of the year 1958, with a value of
1.72 in quality. This zone includes approximately $10 \%$ of the flats in the study.

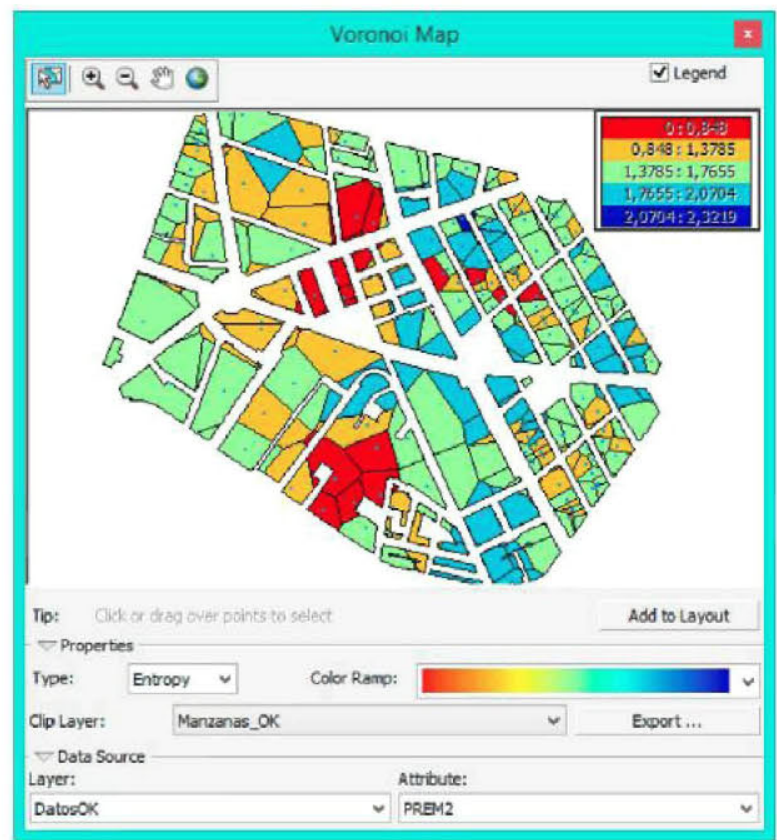

4 Cell grouping as per the Entropy of Unit Prices 


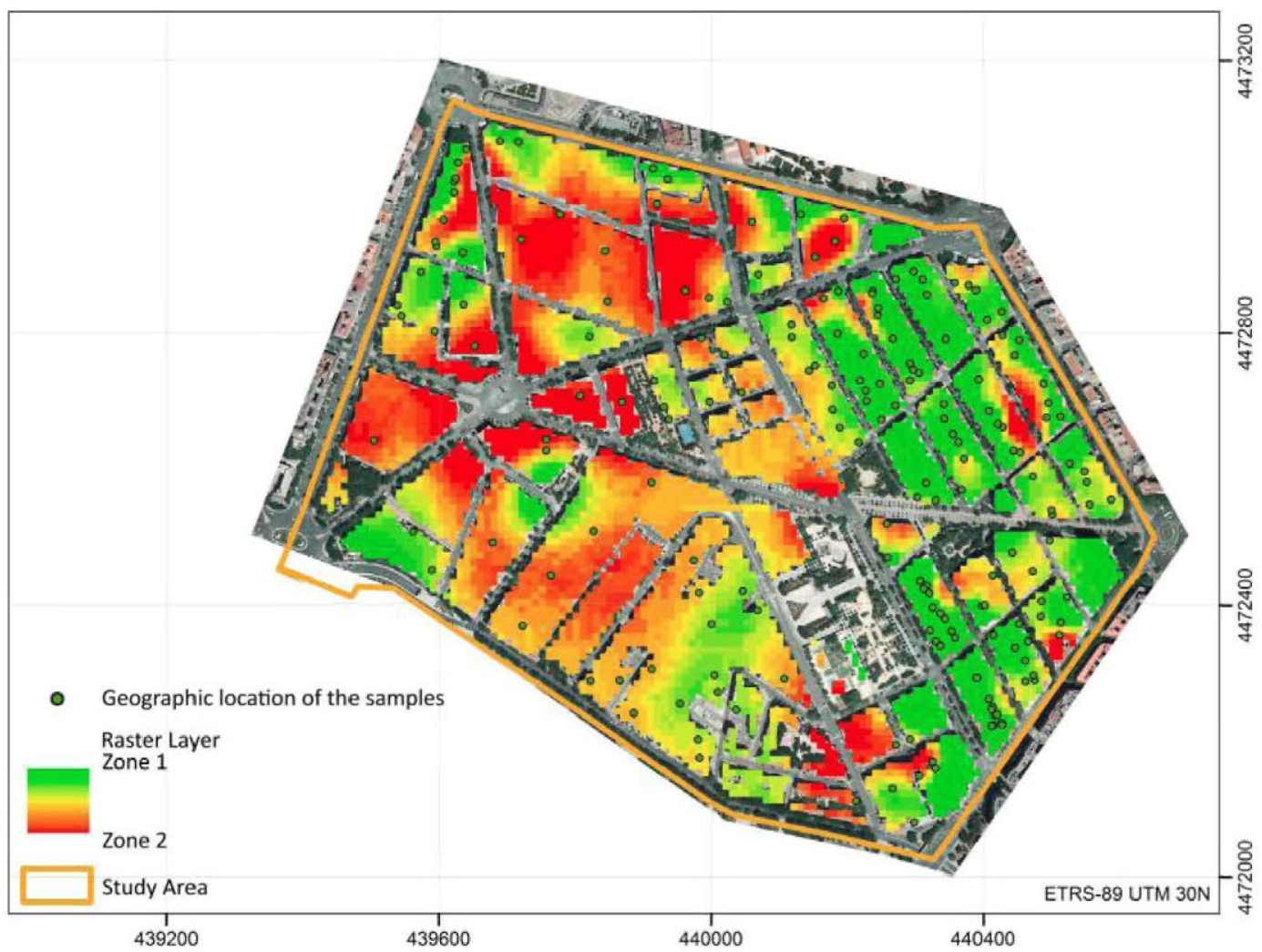

5 Four raster layers superposed with the same units of measure for the four variables

- Zone 3, flats with prices above category 2 of around $€ 2700 / \mathrm{m}^{2}$, a surface area of around $100 \mathrm{~m}^{2}$, an average construction date of the year 1984 , with a value of 2 in quality. This zone includes $8 \%$ of the flats in this study.
- Zone 4, flats with the highest prices of around $€ 3300 /$ $\mathrm{m}^{2}$, a surface area of around $150 \mathrm{~m}^{2}$, an average construction date of the year 2001, with a value of 3 in quality. This zone includes around $32 \%$ of the flats in the study.

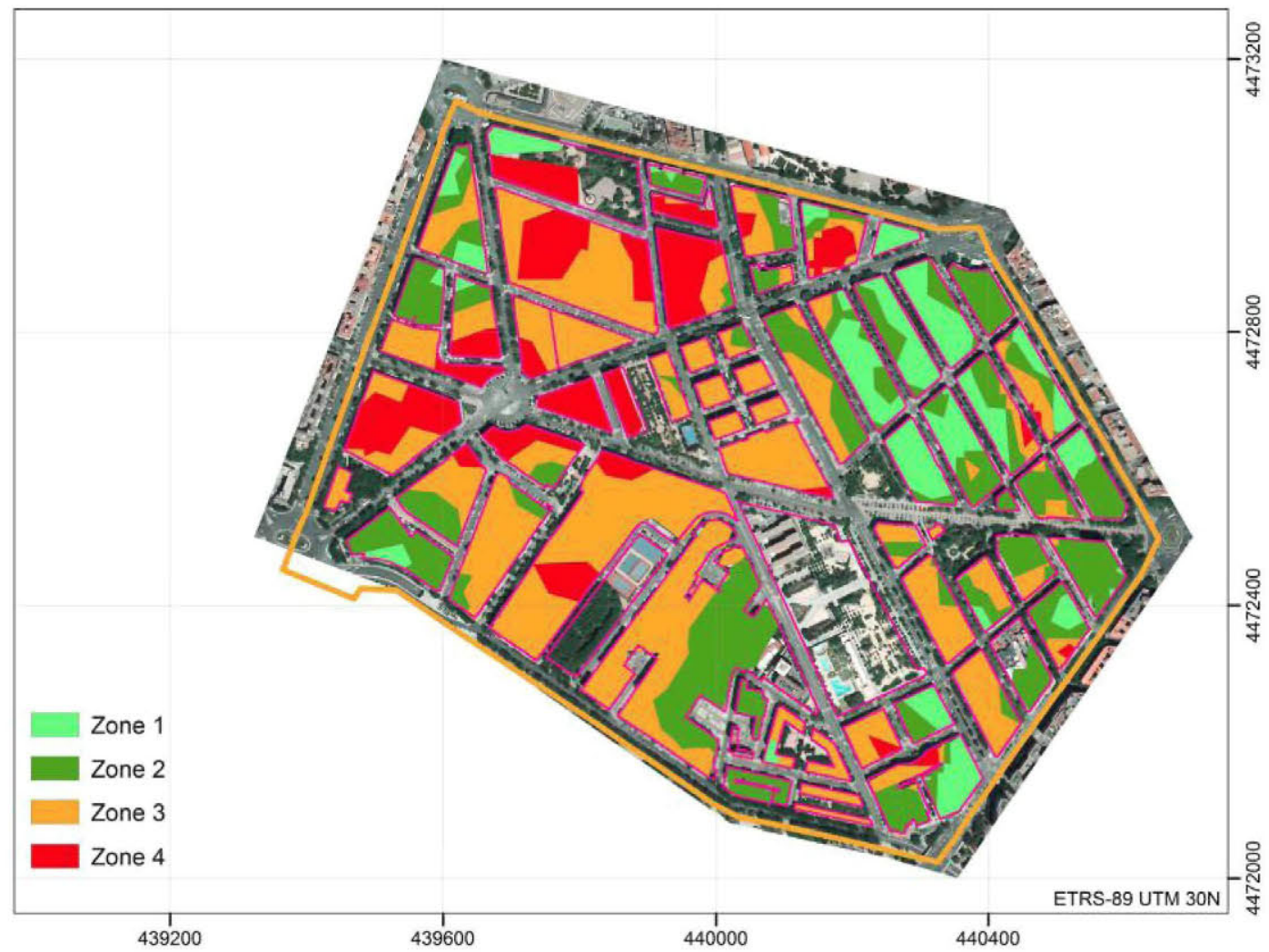

6 Zoning in four categories, according to the colour, obtained by superposing the four raster layers 


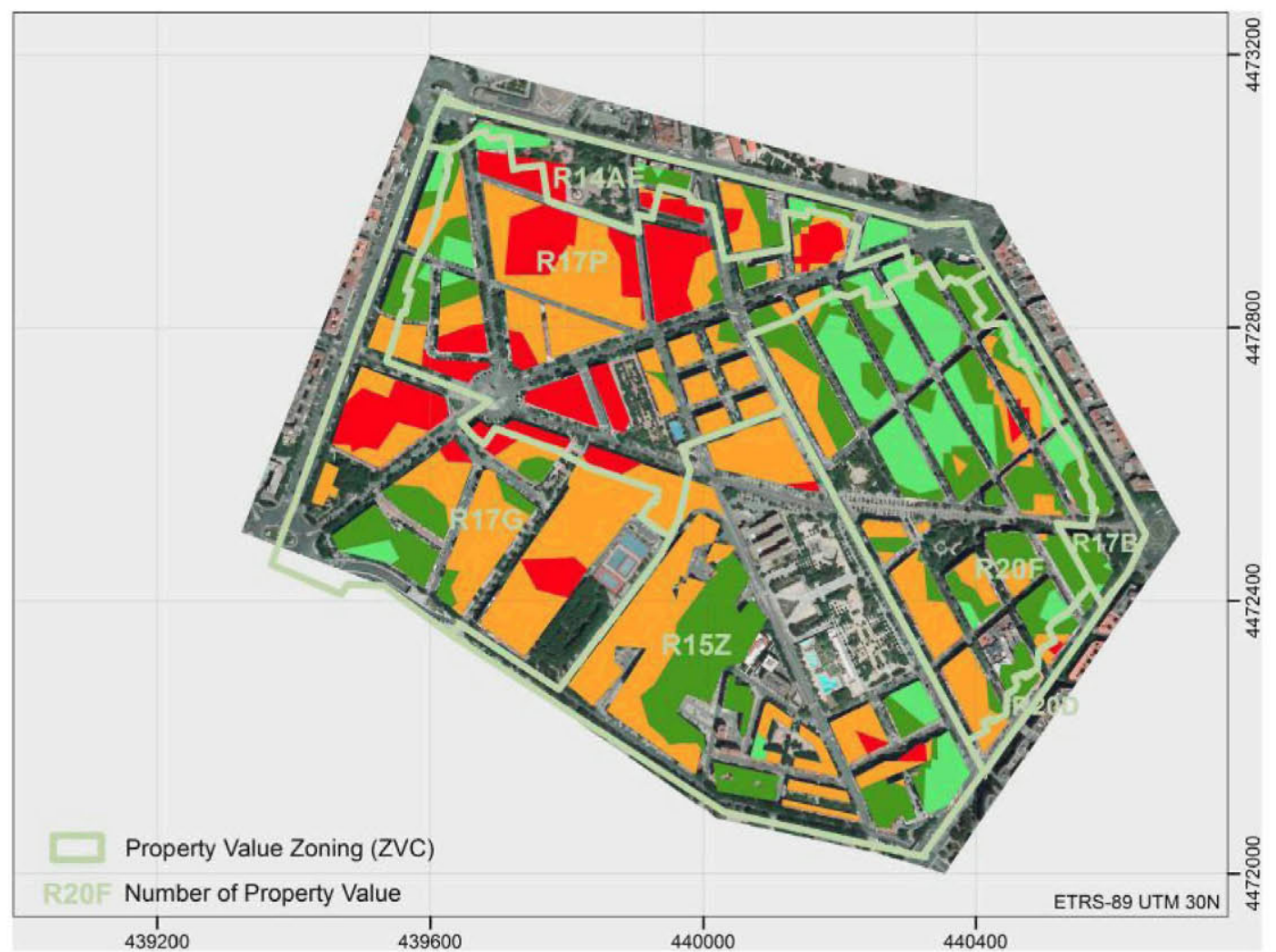

7 Superposition between ZVC (light blue lines) y ZIS (buildings colours)

Finally, we compared the zoning obtained with the Spline interpolation (SIZ) with the Value Zones extracted from the Property Value Report (ZVC) in order to carry out phase 4 to validate the findings obtained. To do so, the findings were validated and the zonings obtained based on the Spline interpolation (SIZ) were compared with the Value Zones extracted from the Property Value Report (ZVC). The raster intersection layer was transformed to a vector polygon so as to compile descriptive and inferential geo-statistics. The findings obtained were as follows:

Table1 represents: the sample size, the averages, the standard deviations of the samples taken in each one of the zones as well as the intervals of confidence at $95 \%$; in other words, there is $95 \%$ confidence that the average populations the samples were taken from are included between the upper and higher limit as shown in said table for each one of the attributes studied.

Upon observing the map (Figure 7), we can see that zone 1 of the property value division contains a higher number of buildings in light green which means the oldest, lowest price buildings per metre squared with the lowest surface areas and worst quality are located there as seen in Table 1. Moreover, there are buildings in dark green which correspond to an approximate increase of $10 \%$ improvements of all the variables. There are a minimum number of buildings in orange and red; these buildings correspond to new structures. Therefore, we can state that there is great coincidence in both zoned areas.

The average value in zone 2 is approximately half of the pink and green zone in SIZ. The unit price in ZVC 2 is higher as the age in ZCV 2 is less by 25 years. Zones 3 and 4 practically coincide. Zone 4 includes more modern flats; hence, the prices are somewhat higher there.
However and as has been observed, the prices are similar in both cases and these zones could even be joined together. We have verified that zone 3 shows the average attributes for surface area, age and category.

Table 2 shows these results between the values provided by the Land Registry (ZVC) and those obtained via Spline interpolation (ZIS).

There are obvious differences in the unit prices between ZVC and ZIS as a result of the different methods used. The Land Registry (ZVC) introduces all of the traditional appraisal variables (explained above) whereas these parameters have been reduced and prioritised in the study. In general, the observation is that the average $\mathrm{ZVC}$ values are always higher than the ZIS values; in the worst case scenario, by $18 \%$ except zone 4 where the appraisals change as a result of the fact that the value assigned to the ZIS quality increases much more than the appraisal value assigned by $Z \mathrm{VC}$.

Therefore, the ZVC and SIZ zoning situations show an acceptable overlap of around $85 \%$. The remaining $15 \%$ can be explained by the singularities of certain points with respect to the parameters chosen. This means the SIZ zoning system is a good tool to use when assessing the unit prices of the different zones.

\section{Findings}

This study verifies and confirms a desire to zone and estimate homogeneous areas (neighbourhoods) within a district or, as is the case at hand, in a city, for assessment purposes. The importance of this work is to reduce the number of basic parameters needed to establish value zones. It is clear that the basic parameters are: unit 
Table 1 Spline interpolation zoning (SIZ). Geo-statistics

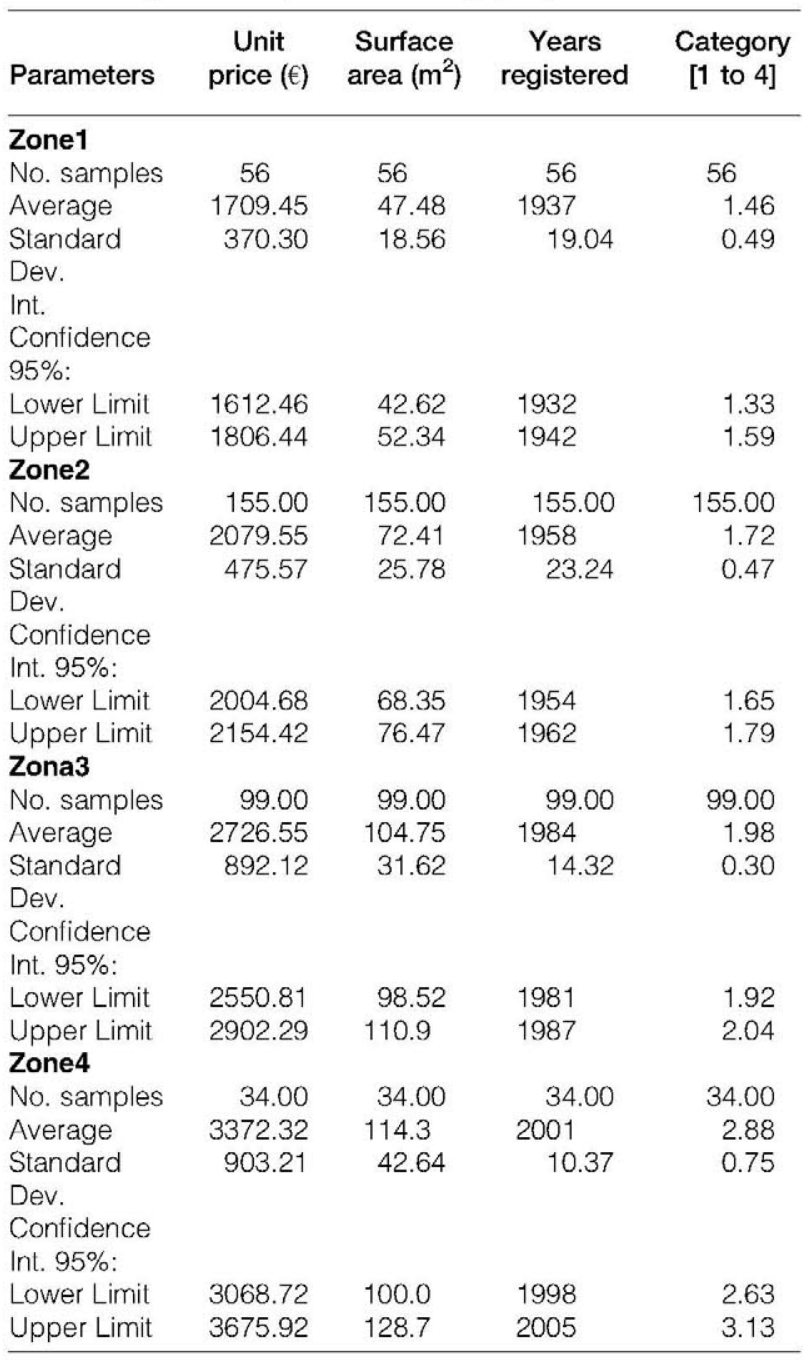

price, surface area, years of construction and the quality of the construction.

The methodology followed is based on selecting the minimum necessary variables with the property registry valuation work fulfilling official technical regulations and considering a higher number of parameters and corrective coefficients (Property Value Report). The findings obtained using both methodologies largely coincide which allows us to state that the methodology using the four parameters selected simplifies the forecast calculations which was the intended objective sought for this research.

The zoning completed for our study (SIZ) shows isolated structures with unit price values that are different from the average of the structures surrounding them. They create isolated points which we have attributed to very modern structures.

\section{Discussion}

The results section above as well as the observations at the end mention that ZVC 3 and 4 practically coincide. Therefore, it is obvious that these two zones in the Cadastre could be included in a single zone so the unitary prices, average surfaces, age and quality show increasing trends without the anomaly observed in said zones. This would provide for better coherence concerning these parameters
Table 2 Results between the values as per the Land Registry (ZVC) and those obtained via Spline interpolation (SIZ)

\begin{tabular}{lcccc}
\hline Averages & $\begin{array}{c}\text { Unit price } \\
\left(€ / \mathrm{m}^{2}\right)\end{array}$ & $\begin{array}{c}\text { Surface } \\
\text { area }\left(\mathbf{m}^{2}\right)\end{array}$ & $\begin{array}{c}\text { Years } \\
\text { registered }\end{array}$ & $\begin{array}{c}\text { Quality } \\
{[1 \text { to 4] }}\end{array}$ \\
\hline ZVC 1 (R20F) & $\mathbf{1 9 6 4 , 3 8}$ & $\mathbf{6 8 , 7 4}$ & $\mathbf{1 9 5 5}$ & $\mathbf{1 , 6 2}$ \\
SIZ 1 & 1709,45 & 47,48 & 1937 & 1,46 \\
ZVC 2 (R15Z) & $\mathbf{2 5 1 2 , 5 0}$ & $\mathbf{9 2 , 7 0}$ & $\mathbf{1 9 8 3}$ & $\mathbf{1 , 9 6}$ \\
SIZ 2 & 2079,55 & 72,41 & 1958 & 1,72 \\
ZVC 3 (R17G) & $\mathbf{2 8 9 1 , 3 1}$ & $\mathbf{1 0 4 , 0 4}$ & $\mathbf{1 9 8 4}$ & $\mathbf{2 , 0 6}$ \\
SIZ 3 & 2726,55 & 104,75 & 1984 & 1,98 \\
ZVC 4 (R17P) & $\mathbf{2 7 8 2 , 7 8}$ & $\mathbf{8 6 , 7 6}$ & $\mathbf{1 9 7 5}$ & $\mathbf{2 , 3 2}$ \\
Media 1 SIZ 4 & 3372,32 & 114,38 & 2001 & 2,88 \\
\hline
\end{tabular}

in ZVC. Nonetheless, we have preferred to respect the zoning as done for the Cadastre. It is clear that this could be subject to debate as to the suitability or lack thereof of said cadastral zonings as the ZIS zonings clearly indicate that the idea division gives rise to three value zones.

\section{Conclusions}

One of the most important conclusions is the validity of the use of these interpolation techniques along with GIS techniques to evaluate spatial correlations as Tobler's Law [Tobler, 1970] is behind each interpolation technique. This law helps select and prioritize the most influential variables in the study area.

On the other hand, it is worth indicating that future studies should be aimed at improving and enriching zoning as well as valuations, not necessarily for taxation purposes, by introducing other dynamic and complementary parameters that may help improve the model such as: bus stops, underground stops, taxi ranks, schools, healthcare infrastructure (hospitals, health centres), etc.

\section{Special thanks}

We would like to give special thanks to the Directorate General of the Property Tax Register for all of the assistance received.

\section{ORCID}

M.C. Morillo (D) http://orcid.org/0000-0002-0788-8394

F. García Cepeda (D) http://orcid.org/0000-0002-90210022

S. Martínez-Cuevas (D) http://orcid.org/0000-0002-21503251

\section{References}

Anselin, L. 1995. Local Indicators of Spatial Association - LISA. Geographical Analysis, 27, pp.93-115.

Anselin, L. (2001B), "Spatial econometrics. 2001 Summer course". University of Illinois, Urbana-Champaing.

Anselin, L. and Le Gallo, J. 2006. Interpolation of air quality measures in hedonic house price models: Spatial aspects, Spatial Economic Analysis, 1(1), pp.31-52.

Cano, R., Chica, J., Hermoso, J. A. 2000. Metodologia para la zonificación de una ciudad. Estudios de Economía Aplicada $\mathrm{N}^{\circ}$ 13, 1999. Págs. 23-49. 
Caridad y Ocerín, J. M., Brañas Garza, P., De la Paz Marín, M. 1997. Análisis intraurbano del precio de las características de la vivienda en Córdoba: los barrios menos favorecidos. I Congreso de Ciencia Regional de Andalucía: Andalucía en el umbral del siglo XXI.

Chasco, C. 2003. Econometría espacial aplicada a la predicción extrapolación de datos microterritoriales, Comunidad de Madrid.

F. Döner. 2015. Evaluation of cadastre renovation studies in Turkey Survev Review, 47(341), pp. 141-152.

Garcia Cepeda F. 2012. Apuntes Asignatura Catastro y Gestión de la Propiedad. ETSITGC. Universidad Politécnica Madrid.

Haining, R. F. 1990. Spatial data analysis in the social and environmental sciences. Cambridge: Cambridge University Press

Ingram Gregory K. 2014. Defining Metropolitan and Megapolitan Areas. Lincoln Institute of Land Policy.

Jansson, M., Axel A. Función de precios hedónicos de viviendas y adaptación del test reset en modelos no lineales. Aplicación del modelo Box \& Cox a los precios de las viviendas de la ciudad de Catamarca, Argentina Pharos [online] 2000, 7 (NoviembreDiciembre): [Date of reference: 23 / agosto / 2015] Available in: $<$ http://4www.redalyc.org/articulo.oa?id=20807205> ISSN 0717 1307

Jahanshiri Ebrahim, Taher Buyong and Abdul Rashid Mohd Shariff. 2011. A review of property mass valuation models. Pertanika Journal of Science \& Technology. 19, pp.23-30.

Junta de Castilla y León. Regional Ministry of the Environment and Territorial Planning. 1994. Modelo funcional de la territorialización de servicios en Castilla y León. Prepared by Guillermo Ramírez Estévez and José Mauro Reguera de Castro. Valladolid.

Li Yan and Mengting Wang. 2014. The Unity Valuation Approach in Mass Appraisal of Real Properties: a Case Study for Shenzhen. FIG Congress. China, PR. Paper 6799.

Metzenbaum, James, 1955 The law of zoning. [New York]Baker, Voorhis

Mitásová H., Mitás L. 1993. Interpolation by regularized spline with tension: I. Theory and Implementation. Mathematical Geology, 25(6), pp. $641-655$.

Moran, P. 1948. The interpretation of statistical maps, Journal of the Royal Statistical Society. Series B (Methodological), 1(2), pp.243251.

Moreno Gallo, I. 2004. Topografía Romana. Elementos de Ingeniería Romana. Libro de Ponencias. Congreso Europeo "Las obras públicas romanas". Tarragona

Navascues Palacio 1969. La Ciudad Lineal de Arturo Soria. "Villa de Madrid' (n. 28); pp. 49-58.

Official Spanish Gazette, of 22 July 1993. Spanish Royal Decree 1020/ 1993 of 25 June, which approves the Technical Valuation Standards and the Framework Chart of Land and Structure Values to determine the Property Tax value of Urban Buildings.

Olaya, V. 2015. Sistema de Información Geográfica. Online book.

Pelletier, A. 1982. L'Urbanisme Romain sous L'Empire. Paris

Reordenación municipal: una propuesta metodológica aplicada a la provincia de León. José Cortizo Álvarez, Antonio Maya Frades, José
María Redondo Vega. Xeográfica, Revista de Xeografía, Territorio e Medio Ambiente $\mathrm{N}^{\circ}$ 6, 2006, 33-53, ISSN 1578-5637.

Ruiz Morales, M. 1999. Comentarios sobre Cartografia histórica. Topografía y Cartografía: Revista del ilustre Colegio de Ingenieros Técnicos en Cartografia. Vol. $3 \mathrm{n}^{\circ} 45$, pp. 9-22.

Sánchez S. 2004. El estudio econométrico de la concentración espacial de la industria: Ejemplo de aplicación en Madrid, Toledo y Guadalajara, Anales de Geografia, $\mathrm{n}^{\circ}$ 24, pp. 207-227. ISSN: 0211-9803.

Santos Preciados J. M. 2011. Los Sistemas de Información Geográfica Vectoriales: El funcionamiento de ArcGis. UNED, pp.257-258

Schweikert, D. G. 1966. An interpolation curve using splines in tensión. JMP 45, pp.312-317.

Shlomo, Angel, Jason Parent, and Daniel L. Civco. 2010. The fragmentation of urban footprints. Lincoln Institute of Land Policy.

Tobler Waldo R. 1970. A computer movie simulating urban growth in the Detroit Region. Economic Geography, 46, pp.234-240

Tomlin D. 1990. Geographic information systems and cartographic modeling. New Jersey: Prentice Hall, ISBN 9780133509274.

Uniform Appraisal Standards for Federal Land Acquisitions. Appraisal Institute 875 North Michigan Ave., Suite 2400, Chicago.

\section{Websites}

ArcGis, 2012. Help. [on line].

Available at: < http://help.arcgis.com/es/arcgisdesktop/10.0/help/index. html\#/na/009z00000078000000/> [Accessed 21 July 2015]

Ayuntamiento de Madrid, 2011. Banco de datos.[on line].

Available at: <http://www-2.munimadrid.es/TSE6/control/seleccionDatos Seccion $>$ [Accessed 10 May 2015]

Dirección General de Catastro, 2010. Ponencias de valores.[on line].

Available at: <http://www.catastro.minhap.es/esp/ponencia_valores.asp $>$ [Accessed 6 June 2015]

Dirección General de Catastro, 2010. Sede electrónica.[on line].

Available at: <https://wwwl.sedecatastro.gob.es/> [Accessed 6 October 2015]

FAO, 2015. Valuation approaches and techniques[on line].

Available at: <http://www.fao.org/docrep/005/y4313e/y4313e08.htm> [Accessed 10 September 2015]

Fotocasa, 2005. Comprar casas Madrid Capital.[on line].

Available at: <http://www.fotocasa.es/vivienda/madrid-capital $>$ [Accessed 9 June 2015]

IAAO, 2013. International Guidance Paper on Mass Appraisal of Real Property.[on line].

Available at: <http://www.iaao.org/uploads/Draft_Intl_Mass_Appr_ paper_812012.pdf $>$ [Accessed 8 September 2015]

Idealista, 2000. Pisos Madrid. [on line]

Available at: <http://www.idealista.com/venta-viviendas/madrid-madrid/> [Accessed 9 June 2015]

Ministerio de Fomento,2005. Instituto Geográfico Nacional. [on line].

Available at: <http://www.ign.es/ign/main/index >[Accessed 10 May 2015] 